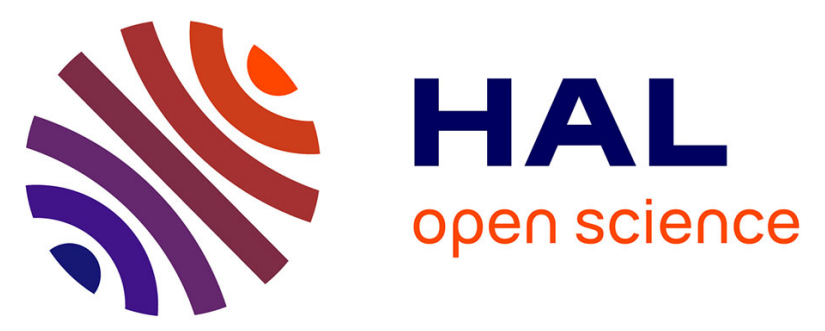

\title{
Pathways to persistence: plant root traits alter carbon accumulation in different soil carbon pools
}

\author{
Lorenzo Matteo Walter Rossi, Zhun Mao, Luis Merino-Martin, Catherine \\ Roumet, Florian Fort, Olivier Taugourdeau, Hassan Boukcim, Stéphane \\ Fourtier, Maria del Rey Granado, Tiphaine Chevallier, et al.
}

\section{To cite this version:}

Lorenzo Matteo Walter Rossi, Zhun Mao, Luis Merino-Martin, Catherine Roumet, Florian Fort, et al. Pathways to persistence: plant root traits alter carbon accumulation in different soil carbon pools. Plant and Soil, 2020, 452, pp.457-478. 10.1007/s11104-020-04469-5 . hal-02879796

\section{HAL Id: hal-02879796 \\ https://hal.inrae.fr/hal-02879796}

Submitted on 27 Nov 2020

HAL is a multi-disciplinary open access archive for the deposit and dissemination of scientific research documents, whether they are published or not. The documents may come from teaching and research institutions in France or abroad, or from public or private research centers.
L'archive ouverte pluridisciplinaire HAL, est destinée au dépôt et à la diffusion de documents scientifiques de niveau recherche, publiés ou non, émanant des établissements d'enseignement et de recherche français ou étrangers, des laboratoires publics ou privés. 
2 Article: Pathways to persistence: plant root traits alter carbon accumulation in different soil carbon

3 pools

4 Lorenzo M.W. Rossi ${ }^{a, b}$, Zhun Mao ${ }^{a}$, Luis Merino-Martín ${ }^{a, c}$, Catherine Roumet ${ }^{c}$, Florian Fort ${ }^{d}$, Olivier 5 Taugourdeau ${ }^{e}$, Hassan Boukcim ${ }^{e}$, Stéphane Fourtier ${ }^{a}$, Maria Del Rey-Granadoc, Tiphaine Chevallier ${ }^{f}$, 6 Rémi Cardinae $\left.\right|^{\mathrm{g}, \ldots,}, \mathrm{N}$, Nathalie Fromin ${ }^{\mathrm{c}}$, Alexia Stokes ${ }^{\mathrm{a}}$

7

8 Contact author: Lorenzo MW Rossi

$9 \quad$ Email: Imw.rossi@gmail.com Address: AMAP, INRAE Montpellier, PS2 TA/A51, 34398 Montpellier cedex 5, France

a) University of Montpellier, AMAP, INRAE, CIRAD, CNRS, IRD, PS2 TA/A51, 34398 Montpellier cedex 5 , France

b) University of Cassino, Via Di Biasio 43, 03043 Cassino (Fr), Italy.

c) CEFE, Univ Montpellier, CNRS, EPHE, IRD, Univ Paul Valéry, Montpellier, France

d) CEFE, CNRS, Univ Montpellier, Univ Paul Valéry Montpellier 3, EPHE, IRD, Montpellier, France

e) Valorhiz, 1900, Boulevard de la Lironde PSIII, Parc Scientifique Agropolis F-34980 Montferrier sur Lez, France.

f) Eco\&Sols, IRD, CIRAD, INRA, University of Montpellier, Montpellier SupAgro, Montpellier, France

g) CIRAD, UPR AIDA, Harare, Zimbabwe.

h) AIDA, University of Montpellier, CIRAD, Montpellier, France

i) Crop Science Department, University of Zimbabwe, Box MP167,Mt. Pleasant, Harare, Zimbabwe 
Table S1: Pearson's correlation coefficients $(r)$ showing relationships between mean root elongation rate and climatic variables.

Variables tested include: mean daily soil temperature, mean daily air temperature, minimum daily air temperature, maximum daily air temperature, mean

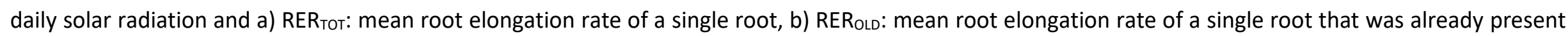
at the previous sampling date (i.e. that were older than 14 days), c) RER $R_{N E w}$ : mean root elongation rate of a single newly initiated root (i.e. that were aged 1 to 14 days). The correlations were performed for data from each RER sampling date, i.e. every 2 weeks for each species over the 10 month period.

\begin{tabular}{|c|c|c|c|c|c|c|}
\hline \multicolumn{7}{|c|}{ a - Correlation between climate factors and RER $_{\text {Tот }}$ of the total root system } \\
\hline & & $\begin{array}{l}\text { Soil } \\
\text { temperature }\end{array}$ & $\begin{array}{l}\text { Mean air } \\
\text { temperature }\end{array}$ & $\begin{array}{l}\text { Minimum air } \\
\text { temperature }\end{array}$ & $\begin{array}{l}\text { Maximum air } \\
\text { teperature }\end{array}$ & $\begin{array}{l}\text { Mean solar } \\
\text { radiation }\end{array}$ \\
\hline \multirow[t]{5}{*}{ Poaceae } & Dactylis glomerata & -0.23 & -0.21 & -0.1 & -0.18 & -0.1 \\
\hline & Lolium perenne & 0.01 & -0.04 & -0.03 & 0.09 & 0.38 \\
\hline & Festuca rubra & -0.21 & -0.27 & -0.34 & -0.2 & 0.15 \\
\hline & Bromus erectus & -0.02 & -0.05 & -0.01 & 0.02 & 0.29 \\
\hline & Poa pratensis & 0.1 & 0.08 & 0.34 & 0.1 & 0.43 \\
\hline \multirow[t]{5}{*}{ Fabaceae } & Trifolium repens & $0.76^{* * * *}$ & $0.81^{* * * *}$ & 0.45 & $0.68 * *$ & 0.33 \\
\hline & Trifolium pratense & 0.02 & -0.02 & -0.02 & 0.09 & 0.4 \\
\hline & Lotus corniculatus & $0.70 * *$ & $0.70^{* * *}$ & 0.44 & $0.68 * *$ & $0.72 * *$ \\
\hline & Onobrychis viciifolia & $a 0.13$ & 0.09 & 0.3 & 0.17 & $0.54 *$ \\
\hline & Medicago sativa & 0.01 & 0.01 & -0.05 & 0.02 & 0.22 \\
\hline Rosaceae & Sanguisorba minor & -0.06 & -0.06 & -0.06 & -0.04 & 0.16 \\
\hline Plantaginaceae & Plantago lanceolata & 0 & -0.04 & 0 & 0.04 & 0.3 \\
\hline
\end{tabular}

\begin{tabular}{cllllll}
\hline \multicolumn{6}{c}{ b - Correlation between climate factors and RER OLD of the old roots } \\
\hline \multirow{5}{*}{ Family } & Species & $\begin{array}{l}\text { Soil } \\
\text { temperature }\end{array}$ & $\begin{array}{l}\text { Mean air } \\
\text { temperature }\end{array}$ & $\begin{array}{l}\text { Minimum air } \\
\text { temperature }\end{array}$ & $\begin{array}{l}\text { Maximum air } \\
\text { teperature }\end{array}$ & $\begin{array}{l}\text { Mean solar } \\
\text { radiation }\end{array}$ \\
\hline Poaceae & Dactylis glomerata & -0.27 & -0.26 & -0.17 & -0.22 & -0.12 \\
& Lolium perenne & 0.14 & 0.13 & 0.31 & 0.09 & 0.21 \\
& Festuca rubra & -0.25 & -0.3 & -0.41 & -0.25 & 0.05 \\
& Bromus erectus & 0.17 & 0.28 & -0.07 & 0.2 & 0.29 \\
& Poa pratensis & -0.03 & 0 & 0.4 & 0.04 & 0.21 \\
Fabaceae & Trifolium repens & 0.28 & 0.28 & 0.15 & 0.4 & 0.45 \\
& Trifolium pratense & 0.18 & 0.25 & -0.07 & 0.24 & 0.38 \\
& Lotus corniculatus & $\mathbf{0 . 7 3 * *}$ & $\mathbf{0 . 7 1} * *$ & 0.51 & $\mathbf{0 . 7 4 * *}$ & $\mathbf{0 . 8 9} * * * *$ \\
& Onobrychis viciifolia & 0.04 & 0.02 & 0.26 & 0.07 & 0.36 \\
Rosaceae & Medicago sativa & 0.03 & 0.01 & -0.05 & 0.03 & 0.23 \\
Plantaginaceae & Sanguisorba minor & 0.13 & 0.2 & -0.08 & 0.1 & -0.33 \\
& Plantago lanceolata & -0.05 & -0.07 & -0.05 & -0.03 & 0.21 \\
\hline
\end{tabular}

\begin{tabular}{|c|c|c|c|c|c|c|}
\hline \multicolumn{7}{|c|}{ c - Correlation between climate factors and $\mathrm{RER}_{\mathrm{NEW}}$ of new roots } \\
\hline & & $\begin{array}{l}\text { Soil } \\
\text { temperature }\end{array}$ & $\begin{array}{l}\text { Mean air } \\
\text { temperature }\end{array}$ & $\begin{array}{l}\text { Minimum air } \\
\text { temperature }\end{array}$ & $\begin{array}{l}\text { Maximum air } \\
\text { teperature }\end{array}$ & $\begin{array}{l}\text { Mean solar } \\
\text { radiation }\end{array}$ \\
\hline \multirow[t]{5}{*}{ Poaceae } & Dactylis glomerata & $-0.55 *$ & $-0.54 *$ & -0.47 & $-0.60^{*}$ & $-0.66^{* * *}$ \\
\hline & Lolium perenne & 0.03 & 0 & -0.05 & 0.1 & 0.29 \\
\hline & Festuca rubra & -0.11 & -0.16 & -0.04 & -0.15 & 0.26 \\
\hline & Bromus erectus & -0.06 & -0.07 & -0.08 & -0.05 & 0.17 \\
\hline & Poa pratensis & 0.09 & 0.08 & 0.36 & 0.06 & 0.38 \\
\hline \multirow[t]{5}{*}{ Fabaceae } & Trifolium repens & $0.59 *$ & $0.67 * *$ & 0.17 & $0.57 *$ & 0.17 \\
\hline & Trifolium pratense & 0.11 & 0.1 & 0.37 & 0.08 & 0.41 \\
\hline & Lotus corniculatus & $0.76^{* * * *}$ & $0.75 * *$ & 0.48 & $0.76^{* * * *}$ & $0.76 * *$ \\
\hline & Onobrychis viciifolic & $a 0.13$ & 0.1 & 0.3 & 0.15 & 0.51 \\
\hline & Medicago sativa & 0.04 & 0.06 & -0.35 & 0.04 & 0.21 \\
\hline Rosaceae & Sanguisorba minor & 0.09 & 0.16 & 0.04 & 0.06 & -0.05 \\
\hline Plantaginaceae & Plantago lanceolata & -0.05 & -0.06 & -0.06 & -0.03 & 0.19 \\
\hline
\end{tabular}


Table S2: Pearson's correlation coefficients $(r)$ showing relationships between cumulative root length production and climatic variables.

Variables tested include: mean daily soil temperature, mean daily air temperature, minimum daily air temperature, maximum daily air temperature, mean daily solar radiation and a) RLP $\mathrm{TOT}_{\text {: }}$ cumulative root length production of the 30 roots that were analysed, b) RLPoLD: cumulative root length production of roots

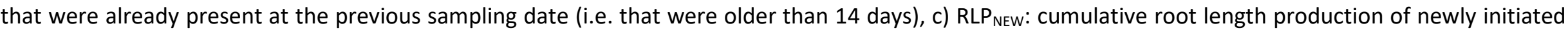
roots (i.e. that were aged 1 to 14 days). The correlations were performed for data from each RLP sampling date, i.e. every 2 weeks for each species over the 10 month period.

\begin{tabular}{cllllll}
\hline \multicolumn{6}{c}{ a - Correlation between climate factors and RLP } & \multicolumn{3}{l}{ of the total root system } \\
\hline & & $\begin{array}{l}\text { Soil } \\
\text { temperature }\end{array}$ & $\begin{array}{l}\text { Mean air } \\
\text { temperature }\end{array}$ & $\begin{array}{l}\text { Minimum air } \\
\text { temperature }\end{array}$ & $\begin{array}{l}\text { Maximum air } \\
\text { teperature }\end{array}$ & $\begin{array}{l}\text { Average solar } \\
\text { radiation }\end{array}$ \\
\hline Poaceae & Dactylis glomerata & -0.4 & -0.41 & -0.46 & -0.45 & -0.38 \\
& Lolium perenne & -0.02 & -0.05 & -0.08 & 0.04 & 0.29 \\
& Festuca rubra & -0.19 & -0.25 & -0.32 & -0.18 & 0.18 \\
& Bromus erectus & -0.01 & -0.05 & 0.01 & 0.03 & 0.31 \\
& Poa pratensis & 0.12 & 0.09 & 0.35 & 0.12 & 0.46 \\
Fabaceae & Trifolium repens & 0.36 & 0.37 & -0.01 & 0.33 & 0.38 \\
& Trifolium pratense & 0.03 & 0 & 0.03 & 0.07 & 0.34 \\
& Lotus corniculatus & $\mathbf{0 . 7 2} * *$ & $\mathbf{0 . 7 2} * *$ & 0.46 & $\mathbf{0 . 7 0} * *$ & $\mathbf{0 . 7 4} * *$ \\
& Onobrychis vicifolia & 0.13 & 0.09 & 0.3 & 0.17 & $\mathbf{0 . 5 4 *}$ \\
Rosaceae & Medicago sativa & 0.01 & -0.01 & -0.04 & 0.02 & 0.24 \\
Plantaginaceae & Sanguisorba minor & -0.06 & -0.07 & -0.05 & -0.04 & 0.18 \\
& Plantago lanceolata & 0 & -0.04 & 0 & 0.04 & 0.31 \\
\hline
\end{tabular}

\begin{tabular}{|c|c|c|c|c|c|c|}
\hline \multicolumn{7}{|c|}{ b - Correlation between climate factors and RLP ${ }_{\text {OLD }}$ of the old roots } \\
\hline & & $\begin{array}{l}\begin{array}{l}\text { Soil } \\
\text { temperature }\end{array} \\
\end{array}$ & $\begin{array}{l}\text { Mean air } \\
\text { temperature }\end{array}$ & $\begin{array}{l}\text { Minimum air } \\
\text { temperature }\end{array}$ & $\begin{array}{l}\text { Maximum air } \\
\text { teperature }\end{array}$ & $\begin{array}{l}\text { Mean solar } \\
\text { radiation }\end{array}$ \\
\hline \multirow[t]{5}{*}{ Poaceae } & Dactylis glomerata & -0.29 & -0.34 & -0.38 & -0.28 & 0 \\
\hline & Lolium perenne & 0 & -0.07 & -0.02 & -0.08 & 0.24 \\
\hline & Festuca rubra & -0.16 & -0.22 & -0.31 & -0.15 & 0.19 \\
\hline & Bromus erectus & 0.18 & 0.25 & 0 & 0.23 & 0.38 \\
\hline & Poa pratensis & 0.02 & 0.03 & 0.4 & 0.1 & 0.31 \\
\hline \multirow[t]{5}{*}{ Fabaceae } & Trifolium repens & 0.28 & 0.26 & 0.2 & 0.41 & $0.51 *$ \\
\hline & Trifolium pratense & 0.22 & 0.26 & 0.02 & 0.29 & 0.47 \\
\hline & Lotus corniculatus & $0.72 * *$ & $0.69 * *$ & 0.52 & $0.75 * * *$ & $0.90 * * *$ \\
\hline & Onobrychis viciifolia & 0.06 & 0.03 & 0.28 & 0.1 & 0.42 \\
\hline & Medicago sativa & 0.04 & 0 & 0.02 & 0.08 & 0.33 \\
\hline Rosaceae & Sanguisorba minor & -0.04 & -0.05 & -0.06 & -0.02 & 0.18 \\
\hline Plantaginaceae & Plantago lanceolata & 0 & -0.04 & 0.02 & 0.05 & 0.33 \\
\hline
\end{tabular}

\begin{tabular}{|c|c|c|c|c|c|c|}
\hline \multicolumn{7}{|c|}{$\mathrm{c}$ - Correlation between climate factors and RLP $\mathrm{NEW}_{\mathrm{NEW}}$ of new roots } \\
\hline & & $\begin{array}{l}\text { Soil } \\
\text { temperature }\end{array}$ & $\begin{array}{l}\text { Mean air } \\
\text { temperature }\end{array}$ & $\begin{array}{l}\text { Minimum air } \\
\text { temperature }\end{array}$ & $\begin{array}{l}\text { Maximum air } \\
\text { teperature }\end{array}$ & $\begin{array}{l}\text { Mean solar } \\
\text { radiation }\end{array}$ \\
\hline \multirow[t]{5}{*}{ Poaceae } & Dactylis glomerata & $-0.52 *$ & $-0.51 *$ & -0.51 & $-0.54 *$ & -0.48 \\
\hline & Lolium perenne & -0.25 & -0.3 & -0.43 & -0.27 & 0.04 \\
\hline & Festuca rubra & -0.08 & -0.14 & -0.03 & -0.1 & 0.33 \\
\hline & Bromus erectus & 0.01 & -0.03 & 0.01 & 0.05 & 0.33 \\
\hline & Poa pratensis & 0.13 & 0.1 & 0.34 & 0.12 & 0.46 \\
\hline \multirow[t]{5}{*}{ Fabaceae } & Trifolium repens & $0.51 *$ & $0.57 *$ & 0.11 & 0.49 & 0.26 \\
\hline & Trifolium pratense & 0.17 & 0.14 & 0.36 & 0.17 & $0.51 *$ \\
\hline & Lotus corniculatus & $0.69 * *$ & $0.69 * *$ & 0.41 & $0.70 * *$ & $0.77 * * *$ \\
\hline & Onobrychis viciifolia & 0.06 & 0.01 & 0.02 & 0.13 & 0.43 \\
\hline & Medicago sativa & 0.03 & 0.02 & -0.03 & 0.05 & 0.27 \\
\hline Rosaceae & Sanguisorba minor & 0.17 & 0.14 & 0.19 & 0.22 & 0.46 \\
\hline Plantaginaceae & Plantago lanceolata & 0.01 & -0.03 & 0.01 & 0.05 & 0.32 \\
\hline
\end{tabular}


Table S3: Pearson's correlation coefficients ( $r$ ) showing relationships between root variables and soil variables. Table S3a) shows the significant correlations obtained with the means of the three replicates for every soil and root characteristic for a total of $n=12$. Table S3b) shows the significant Pearson's correlations obtained using all data where $n=34$. Abbreviations: $R_{\text {ER }}$ TOT - root elongation rate of the entire root system; REROLD - of roots older than 14 days; RER $R_{N E W}-$ of new roots aged 1-14 days; RLPTOT - root length production of the entire root system; RLPoLD - of old roots; RLP biomass of a core sampled at 37 weeks; absorptive root diameter- mean diameter of absorptive roots at 37 weeks; hemicellulose + water soluble compounds - concentration of hemicellulose and water soluble compounds in absorptive roots; cellulose, lignin - concentrations of cellulose and lignin in absorptive roots; $\mathrm{C}: \mathrm{N}$ - ratio of carbon to nitrogen in absorptive roots; SIR - microbial substrate induced respiration.

\begin{tabular}{|c|c|c|c|c|c|c|c|}
\hline \multicolumn{8}{|c|}{ a) Pearson's correlations at species level $(n=12$, mean of three replicates) } \\
\hline & & $\Delta \mathrm{C}_{\mathrm{SUM}}$ & $\Delta \mathrm{C}_{\mathrm{POM}}$ & $\Delta \mathrm{C}_{\text {finePOM }}$ & $\Delta \mathrm{C}_{\text {silt }}$ & $\Delta \mathrm{C}_{\text {silt+clay }}$ & SIR \\
\hline \multirow{6}{*}{$\begin{array}{l}\text { Root growth } \\
\text { dynamics }\end{array}$} & $\mathrm{RER}_{\mathrm{TOT}}$ & -0.32 & -0.2 & -0.06 & -0.1 & -0.17 & 0.45 \\
\hline & $\mathrm{RER}_{\mathrm{OLD}}$ & -0.17 & -0.25 & -0.04 & $0.72 * *$ & 0.37 & $0.74 * *$ \\
\hline & $\mathrm{RER}_{\mathrm{NEW}}$ & -0.24 & -0.13 & -0.2 & -0.12 & -0.55 & 0.18 \\
\hline & $\mathrm{RLP}_{\text {тот }}$ & -0.34 & -0.33 & -0.18 & 0.37 & 0.34 & 0.51 \\
\hline & $\mathrm{RLP}_{\mathrm{NEW}}$ & -0.3 & -0.3 & -0.15 & 0.33 & 0.17 & 0.43 \\
\hline & $\mathrm{RLP}_{\mathrm{OLD}}$ & -0.32 & -0.25 & -0.22 & $0.66 *$ & 0.34 & $0.70 *$ \\
\hline \multirow{4}{*}{$\begin{array}{l}\text { Root } \\
\text { morphological } \\
\text { traits }\end{array}$} & Root biomass & -0.2 & -0.46 & -0.37 & $0.78^{* *}$ & 0.3 & $0.80 * *$ \\
\hline & $\begin{array}{l}\text { Absorptive } \\
\text { roots diameter }\end{array}$ & -0.2 & $-0.72 * *$ & -0.17 & $0.79 * *$ & 0.14 & 0.56 \\
\hline & Hemicelluloses & & & & & & \\
\hline & $+\mathrm{H}_{2} \mathrm{O}$ soluble & -0.06 & $-0.61 *$ & -0.13 & $0.82 * *$ & -0.3 & $0.68 *$ \\
\hline \multirow{5}{*}{$\begin{array}{l}\text { Root chemical } \\
\text { traits }\end{array}$} & compounds & & & & & & \\
\hline & Cellulose & -0.18 & 0.47 & -0.14 & -0.22 & 0.19 & -0.53 \\
\hline & Lignin & 0.15 & 0.56 & 0.26 & $-0.84 * * *$ & 0.49 & $-0.60 *$ \\
\hline & Root C:N ratio & 0.26 & 0.37 & 0.09 & $-0.68 *$ & 0.29 & $-0.86 * * *$ \\
\hline & SIR & -0.16 & -0.19 & -0.11 & $0.65^{*}$ & -0.57 & \\
\hline
\end{tabular}

\begin{tabular}{cccccc}
\hline \multicolumn{5}{c}{ b) Pearson's correlations at individual level (n = 34) } \\
\hline$\Delta \mathrm{C}_{\text {SUM }}$ & $\Delta \mathrm{C}_{\mathrm{POM}}$ & $\Delta \mathrm{C}_{\text {finePOM }}$ & $\Delta \mathrm{C}_{\text {silt }}$ & $\Delta \mathrm{C}_{\text {silt+clay }}$ & $\mathrm{SIR}$ \\
\hline-0.32 & -0.2 & -0.06 & -0.1 & -0.17 & 0.45 \\
-0.17 & -0.25 & -0.04 & $\mathbf{0 . 7 2} * *$ & 0.37 & $\mathbf{0 . 7 4} * *$ \\
-0.24 & -0.13 & -0.2 & -0.12 & -0.55 & 0.18 \\
-0.34 & -0.33 & -0.18 & 0.37 & 0.34 & 0.51 \\
-0.3 & -0.3 & -0.15 & 0.33 & 0.17 & 0.43 \\
-0.32 & -0.25 & -0.22 & $\mathbf{0 . 6 6} *$ & 0.34 & $\mathbf{0 . 7 0} *$ \\
0.18 & -0.08 & 0.02 & 0.3 & -0.07 & $\mathbf{0 . 6 9} * * *$ \\
0.08 & $-\mathbf{0 . 4 4 *}$ & 0.21 & 0.14 & 0.36 & $\mathbf{0 . 5 0} * *$ \\
& & & & & \\
0.26 & -0.3 & 0.25 & 0.22 & 0.23 & $\mathbf{0 . 6 0} * * *$ \\
-0.24 & 0.13 & -0.16 & -0.03 & 0.18 & -0.31 \\
-0.19 & 0.18 & -0.17 & -0.21 & -0.26 & $\mathbf{- 0 . 4 6 * *}$ \\
-0.06 & 0.28 & -0.07 & -0.3 & -0.17 & $\mathbf{- 0 . 7 9 * * *}$ \\
0.27 & -0.15 & 0.18 & $\mathbf{0 . 4 8 * *}$ & 0.12 & \\
\hline & & & & &
\end{tabular}

47 In bold, significant $r$ values: ${ }^{*} p<0.05,{ }^{* *} p<0.01,{ }^{* * *} p<0.001$ 
Fig. S1: Spatial disposition of growth boxes.

49 In left panel, replicates are depicted in different colours according to their family (green: $\mathrm{N}_{2}$-fixing Fabaceae, brown: non $\mathrm{N}_{2}$-fixing Poaceae, yellow: non $\mathrm{N}_{2}$ fixing $P$. lanceolata, blue: non $\mathrm{N}_{2}$-fixing $S$. minor). The different shades of colour representing different species are shown in the legend. The blue dot on the upper right-hand corner of the different colored squares shows the boxes that were equipped with air/soil temperature and soil moisture sensors. Soil cores were removed from each row of 'soil core replicates' growth boxes. Half the boxes were fitted with rhizotrons ('rhizotron replicates'). Photographs of each species can be seen in the bottom right panel of the figure.
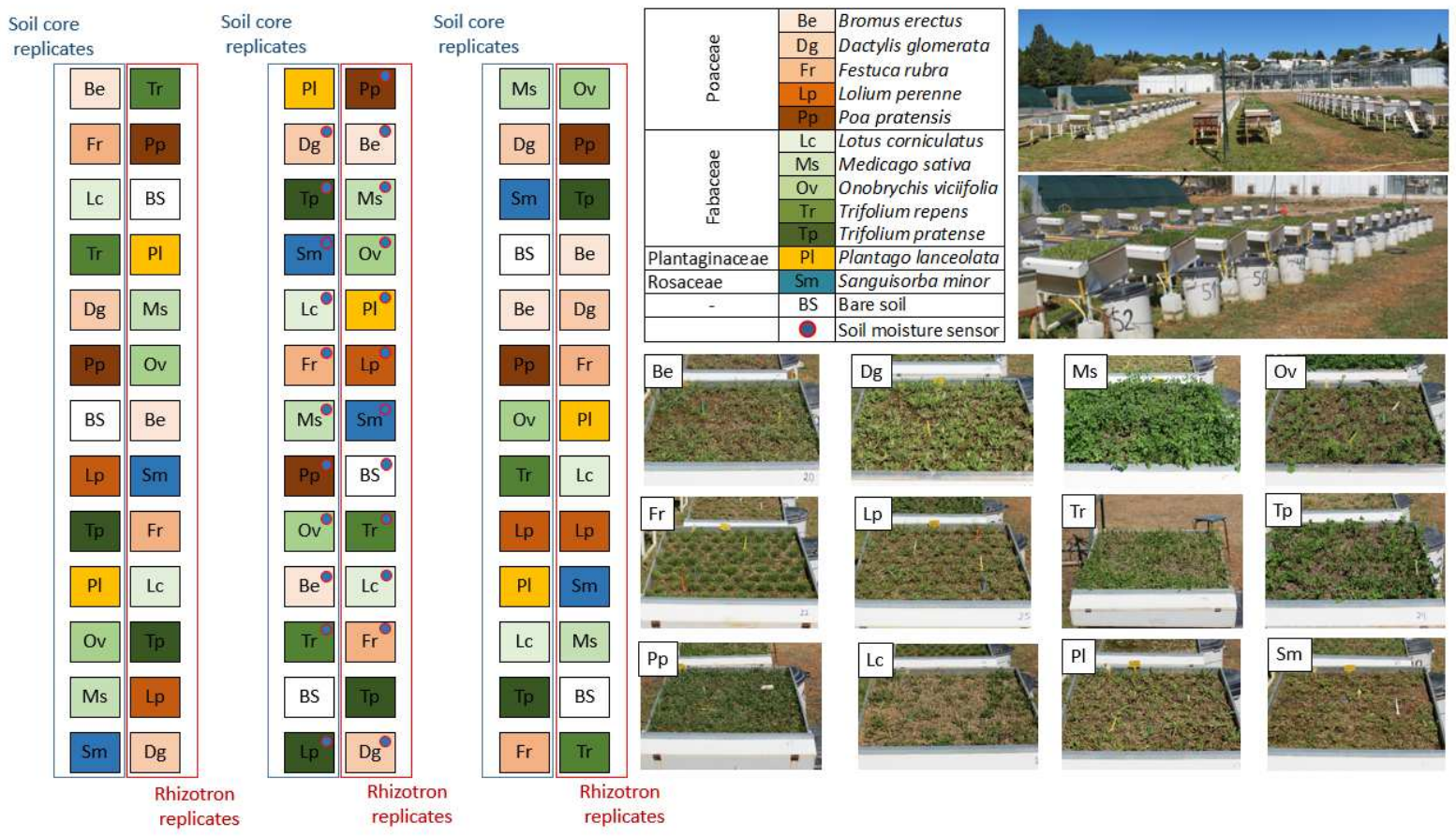
Fig. S2: Growth boxes used in the experiment.

59 Above a gravel layer, soil was homogeneously compacted into growth boxes. Seeds were sown at a 60 density of 155 plants $\mathrm{m}^{-2}$. Panes of plexiglass on the front of the box allowed root elongation to be 61 observed over the 37 week long experiment.

62

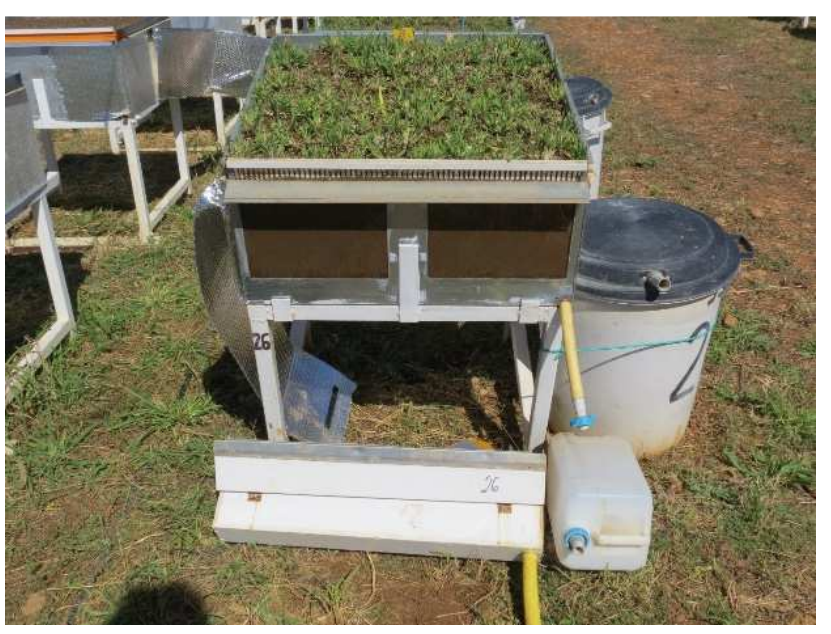

64 
a) Mean daily air temperature (solid black line), minimum air temperature (segmented blue line), maximum air temperature (segmented red line), mean daily soil temperature (dotted black line) and mean daily air humidity (segmented black, dotted line). In b), mean daily solar irradiation (solid black line) and
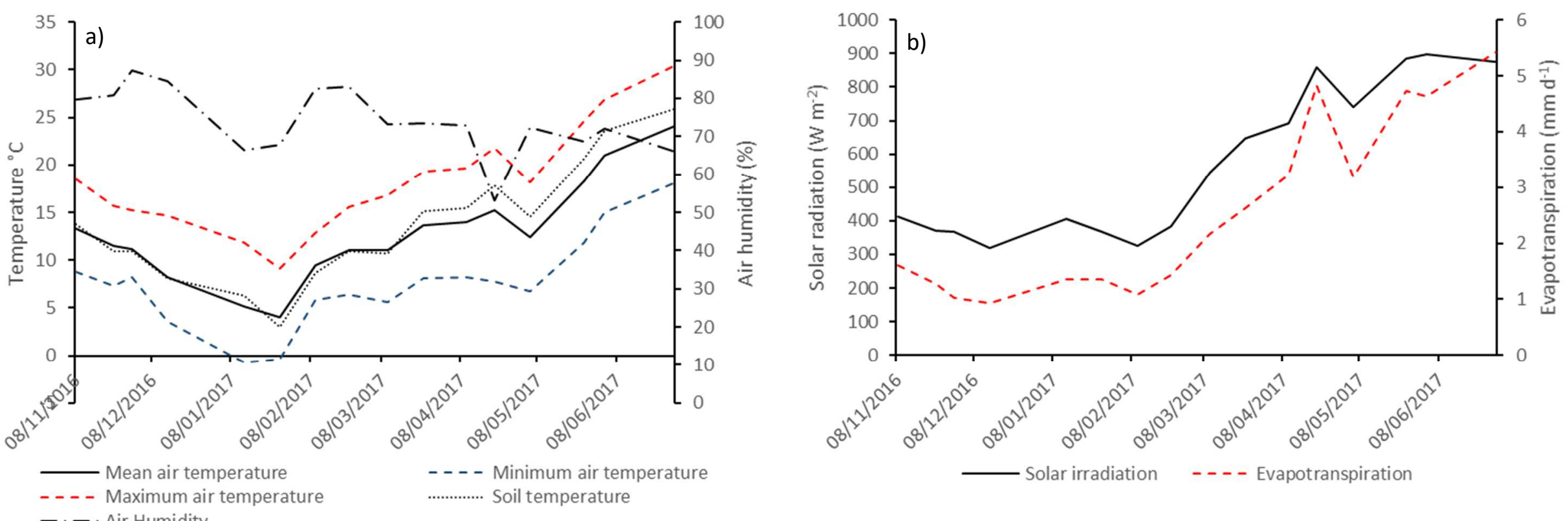
Fig. S4: Example of an image analyzed using SmartRoot software.

a) primary roots (in orange) from which lateral roots are initiated (in green). Each orange circle along the root axis represents a single 'mouse click' for root selection. b) A bundle of roots growing close together, where the number and diameter of roots cannot be recognized by the SmartRoot software.

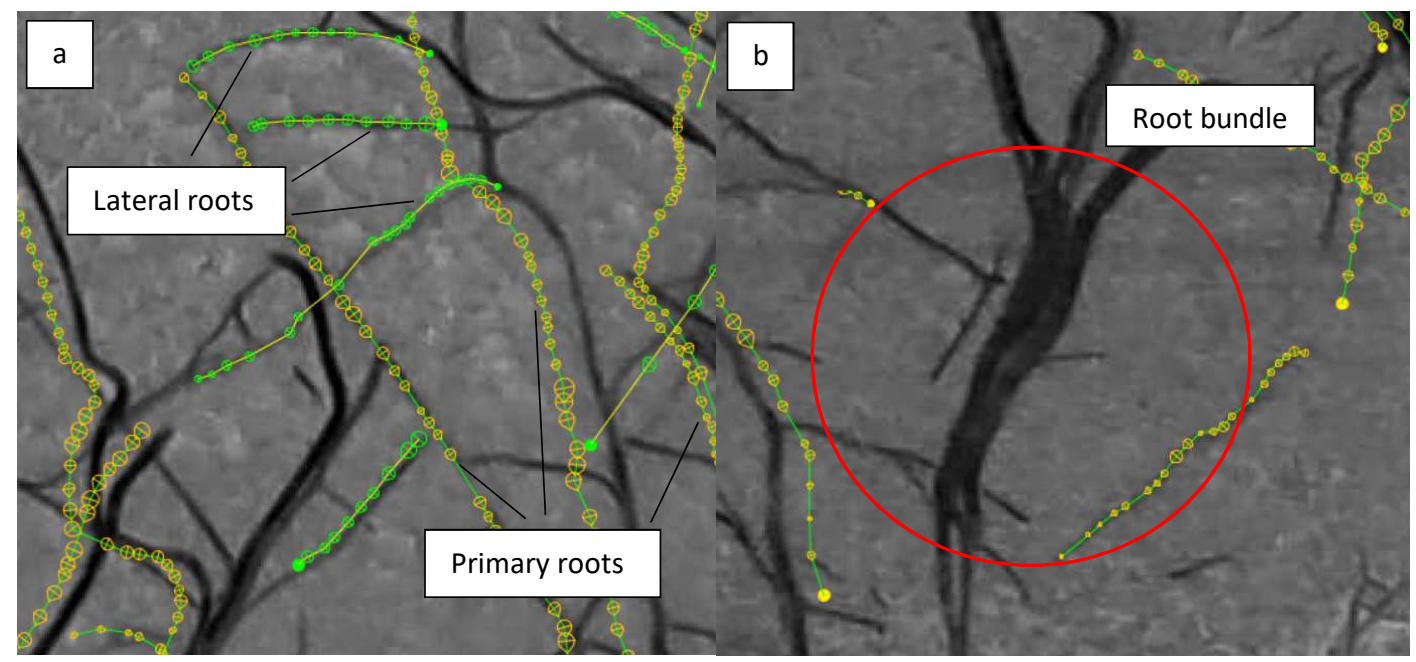

Fig.S5: a) Example of two subsequent images of roots of Bromus erectus taken on 23/02/2019 and $10 / 03 / 2019$ and b) conceptual scheme to explain root selection procedure..

a) The figure on the left shows newly initiated roots that will be analyzed to calculate the RER $R_{N E W}$ and RLP NEW on $23 / 02 / 2019$. At the next date for image analysis (10/03/2019), some of the previously analyzed roots were the same length ( $R E R=0$, middle of the rhizotron), whereas other roots elongated (RER $>0$, bottom of the rhizotron), and were used to calculate RERoLD and RLPoLD. On the top part of the rhizotron, some new roots were initiated, and analyzed to calculate the RER NEW $_{\text {and }}$ RLP NEW $_{\text {on }}$ 10/03/2019. b) Conceptual scheme showing the procedure to select 'old roots' at each sampling: at Time $\times 30$ new roots and 30 old roots have been analyzed. Of these 30 roots, 20 are primary axis roots while 10 second order lateral (Fig. S4a). 10 roots from Time $x$ primary old roots and 10 from Time $x$ primary new roots are randomly selected to be analyzed and constitute the Time $x+1$ old primary roots. 5 roots from Time $x$ secondary old roots and 5 from Time $x$ new secondary roots are selected and analyzed and constitute the Time $x+1$ secondary old roots. 
a)
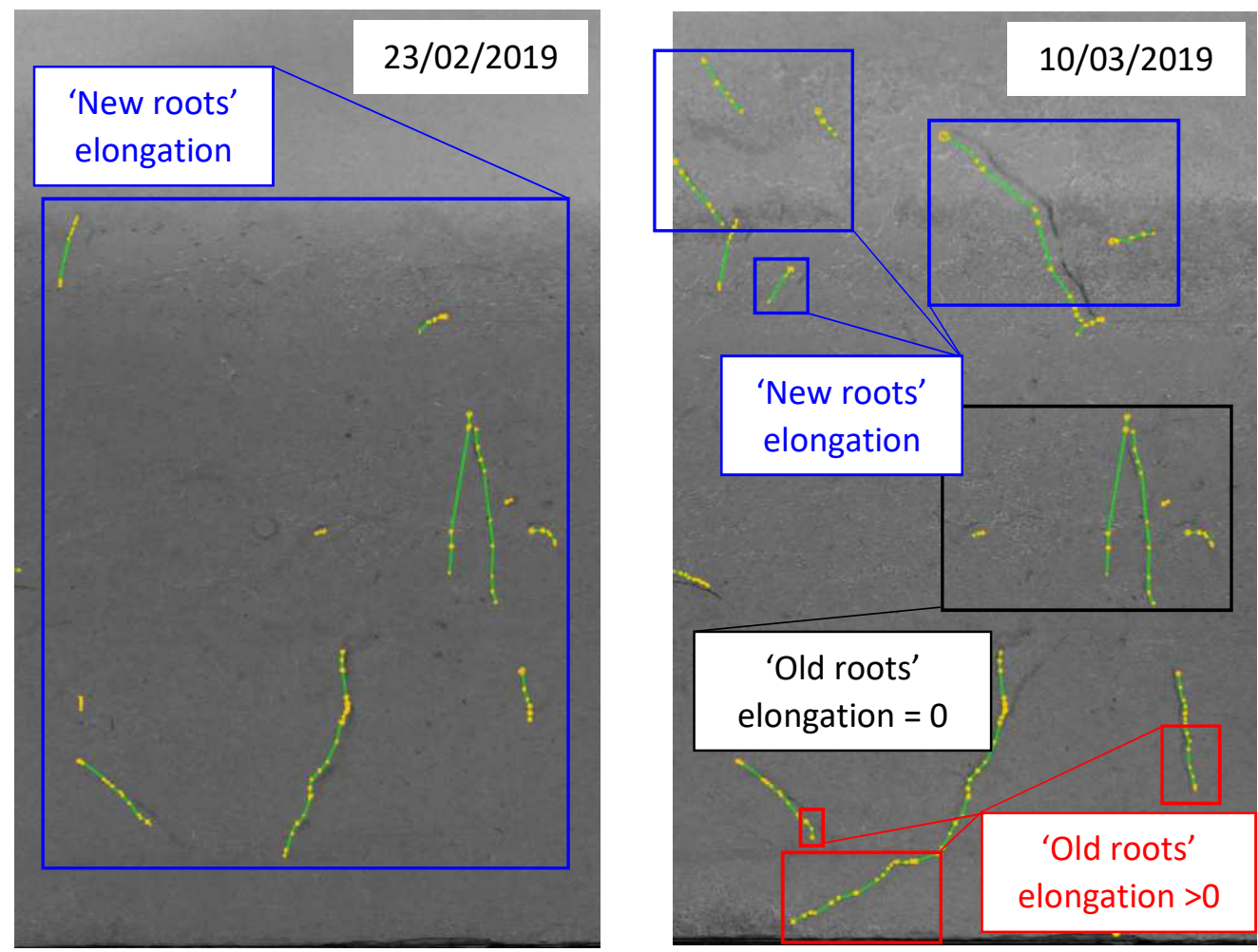

89

b)

\section{0 'Old roots'}

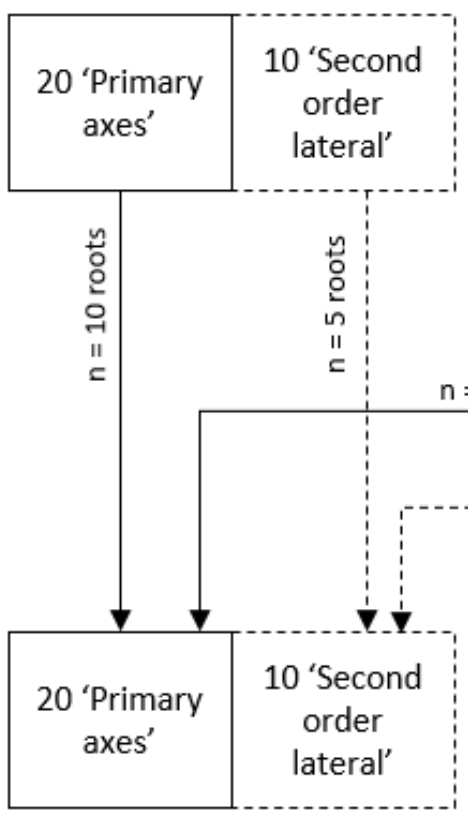

30 'Old roots'

\section{0 'New roots'}

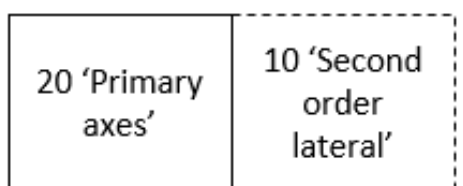

$\mathrm{n}=10$ roots

$n=5$ roots

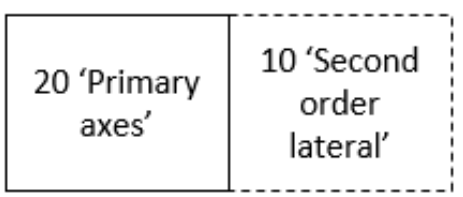

30 'New roots' 
Fig. S6: Carbon (C) content in each soil C pool beneath the 12 species and in the control bare soil, 37 weeks after sowing.

The $C$ pools analyzed are $C_{\text {Pom }}$ in the coarse particulate organic matter $\left.>200 \mu \mathrm{m}\right), C_{\text {finepom }}(C$ in the fine particulate organic matter $200-50 \mu \mathrm{m}$ ), $C_{\text {SILT }}$ (in the coarse silt fraction $50-20 \mu \mathrm{m}$ ) and $\mathrm{C}_{\text {SILT+CLAY }}(\mathrm{C}$ in the fine silt + clay fraction $<20 \mu \mathrm{m})$. The letters on the left hand side of the fraction bars indicate significant differences (Tukey HSD, $p<0.05$ ) between $C$ pools and within species.

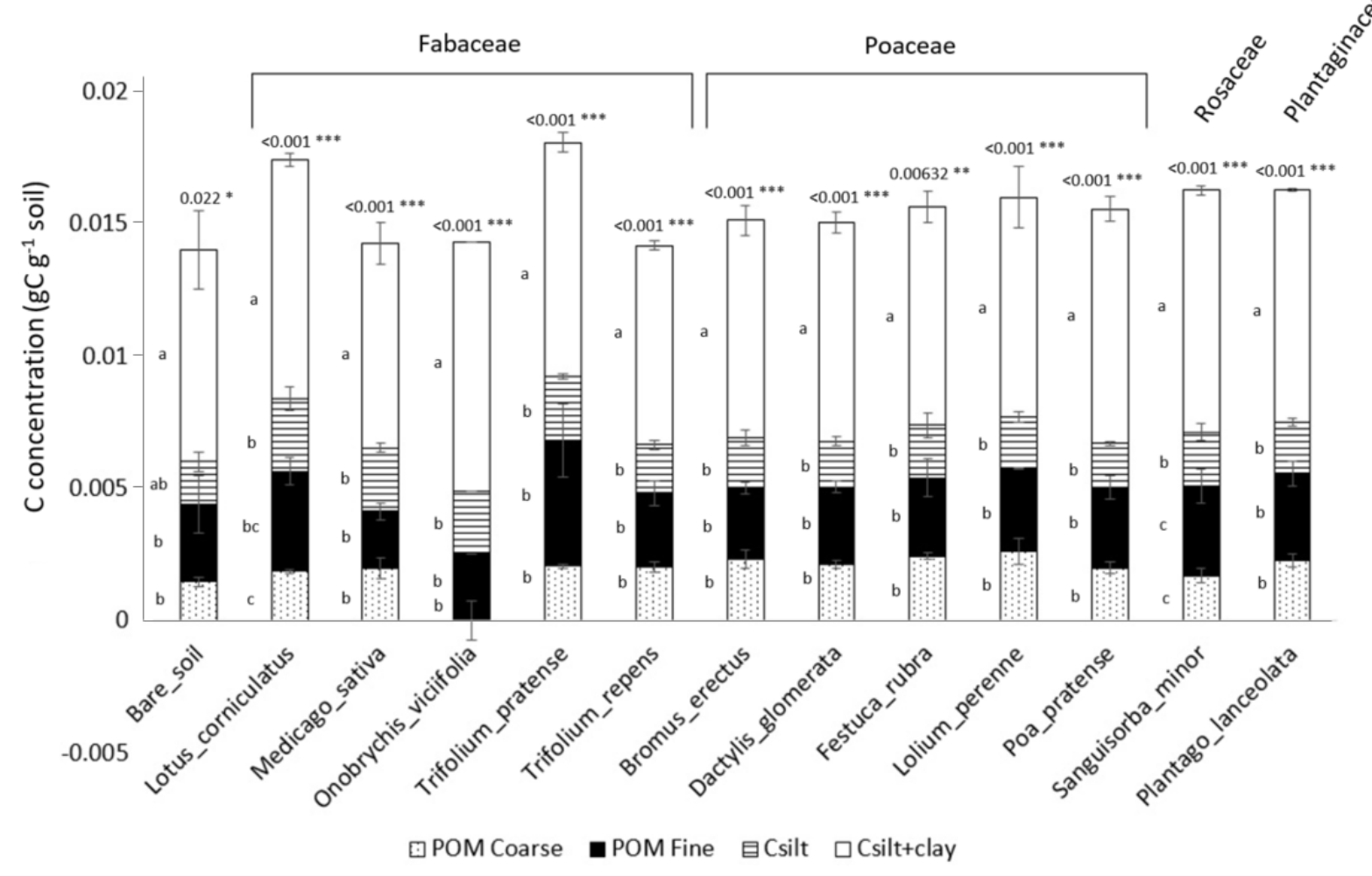


Fig. S7: Mean daily root elongation rate (RERTот) for all the roots analyzed in the rhizotrons (without distinguishing between old and new roots) in Fabaceae ( $\mathrm{N}_{2}$-fixing, black circles) and Poaceae (non $\mathrm{N}_{2}-$ fixing, white squares) family.

102

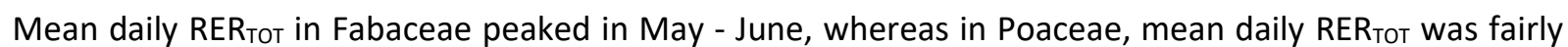

105

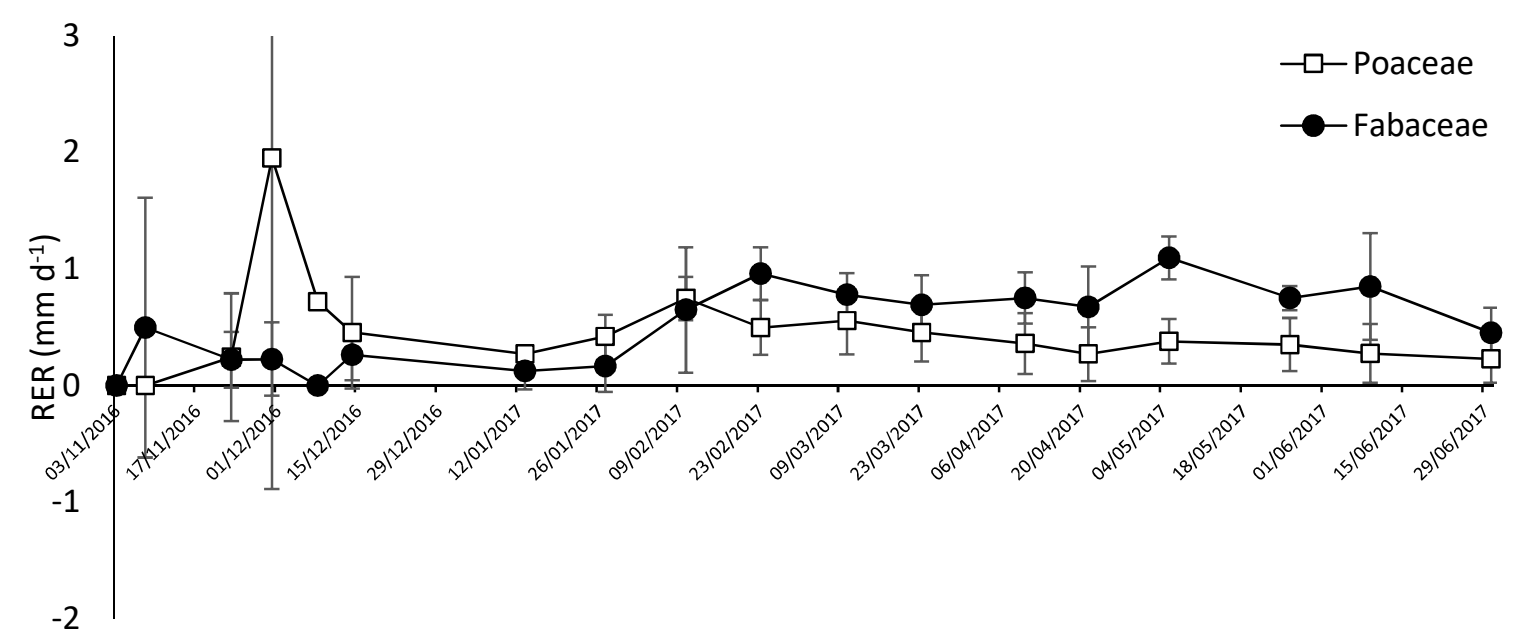


Fig.S8: Mean root elongation rate of individual roots (RER, measured every 2 weeks) for each of the 12 species.

110 The solid black line is the RER $R_{N E W}$ of the roots that were newly initiated (aged 1 to 14 days), and were not present at the previous sampling date. The dotted black line represents the RERoLD of the roots that were already present at the previous sampling date, and so were older than 14 days.
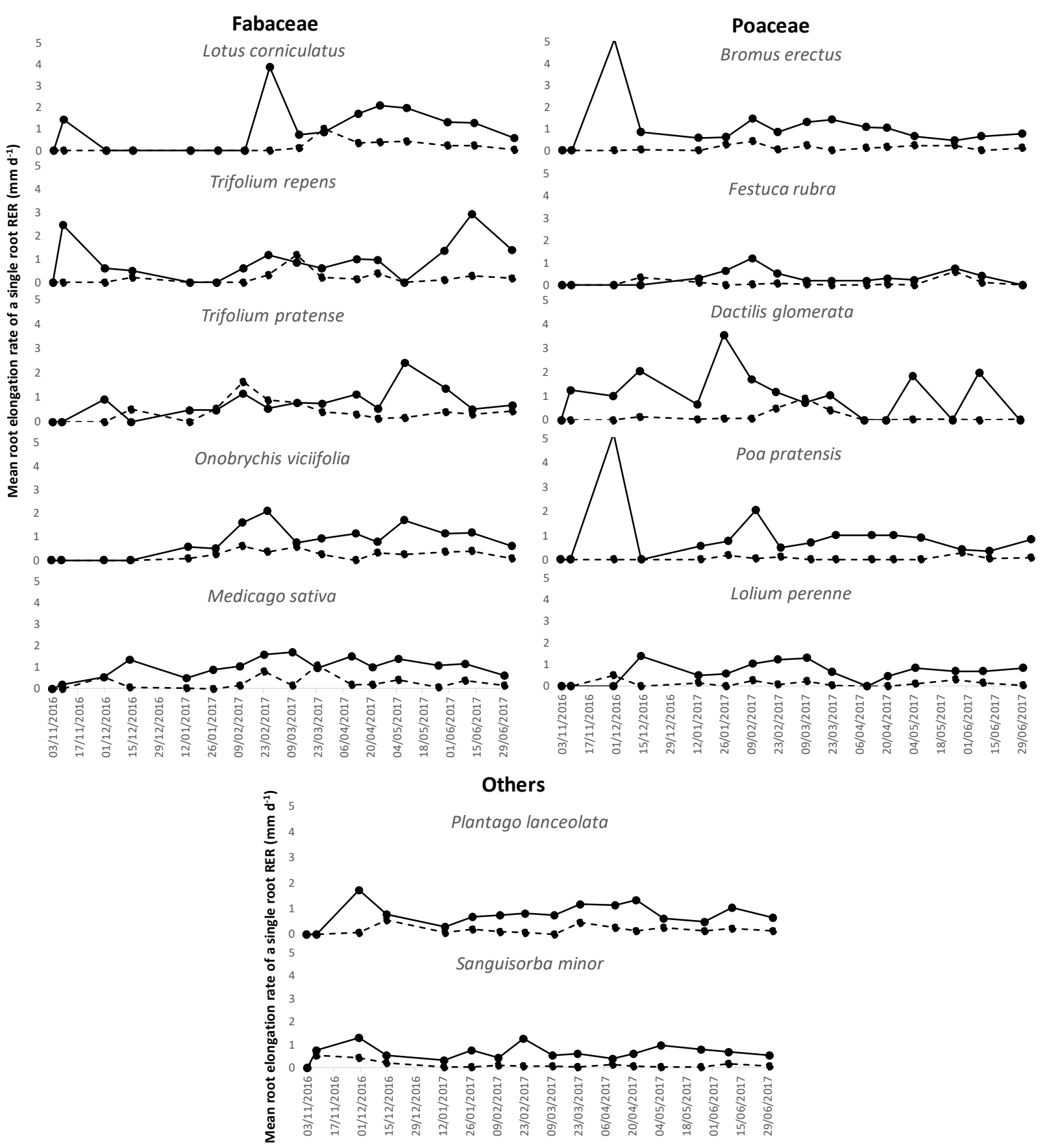
114 Fig. S9: Linear regression at the individual level $\left(n=34\right.$ samples), between $\Delta C_{\text {Ром }}$ (as the difference in 115 carbon (C) in the coarse POM C pool, $\Delta C=C_{t 37}-C_{t 0}$, after 37 weeks), and a) diameter of absorptive roots and b) hemicelluloses + water soluble compounds.

117 The black symbols are the $\mathrm{N}_{2}$-fixing Fabaceae species, the white symbols the non $\mathrm{N}_{2}$-fixing Poaceae species, the red dots are S. minor and the green dots are $P$. lanceolata. The red line is the linear model function of the variables and $R^{2}, F$ and $p$ of the linear model are shown.

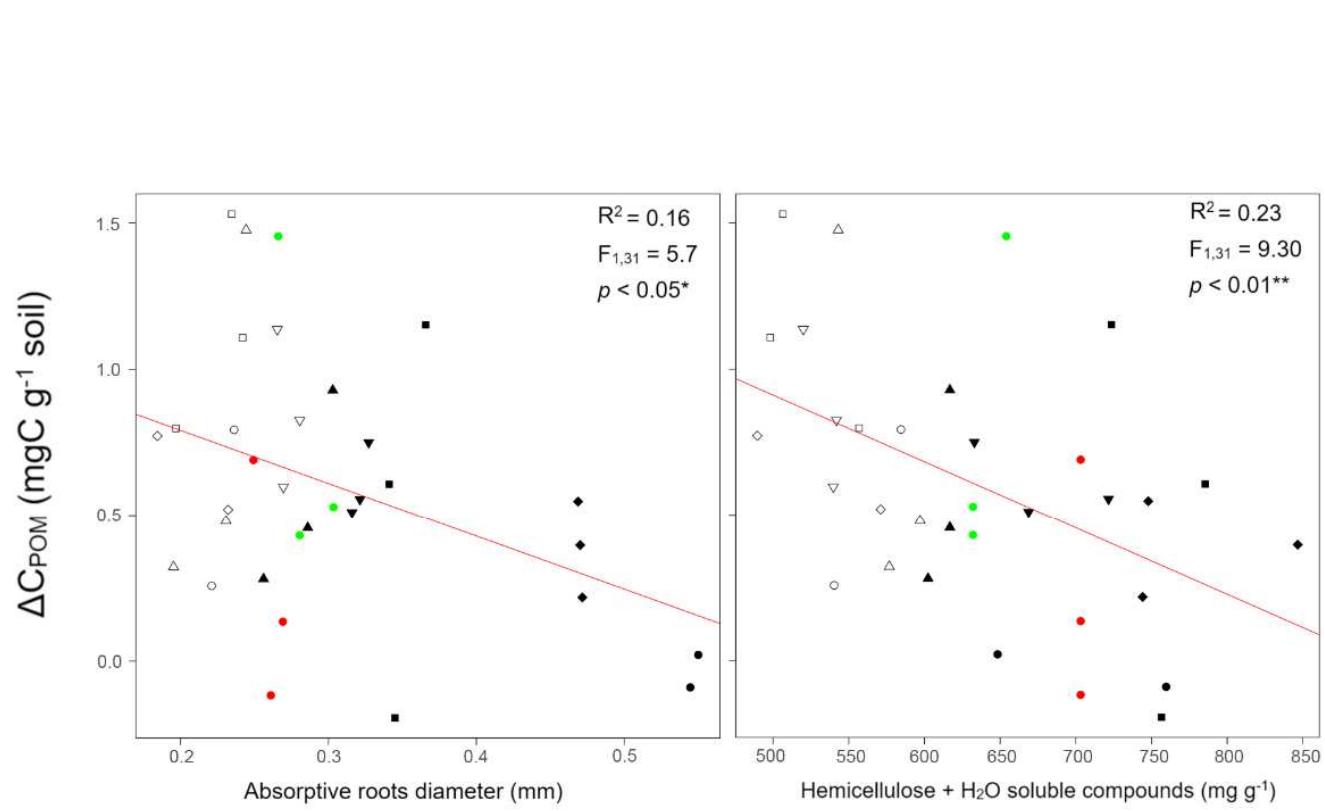

Fabaceae

- L. corniculatus

- O. viciifolia

- M. sativa

- T. pratense

- T. repens

Poaceae

$\diamond$ D. glomerata

- P. pratense

- L. perenne

$\nabla$ B. erectus

$\triangle$ F. rubra

Others

- S. minor

- P. lanceaolata 
122 Fig. S10: Linear regression at individual level $\left(n=34\right.$ samples) between $\Delta C_{\text {silt }}$ (as the difference in carbon 123 (C) in the coarse silt $\mathrm{C}$ pool, $\Delta \mathrm{C}=\mathrm{C}_{\mathrm{t} 37}-\mathrm{C}_{\mathrm{t} 0}$, after 37 weeks), and a) root biomass, b) diameter of absorptive 124 roots, c) lignin content, d) hemicelluloses + water soluble compounds, e) C: $N$ ratio and f) substrate induced 125 respiration rate $(\mathrm{SIR})$.

126 The black symbols are the $\mathrm{N}_{2}$-fixing Fabaceae species, the white symbols the non $\mathrm{N}_{2}$-fixing Poaceae 127 species, the red dots are S. minor and the green dots are $P$. lanceolata. The red line is the linear model 128 function of the variables and $R^{2}, F$ and $p$ of the linear model are shown. For the legend refer to figure S9.
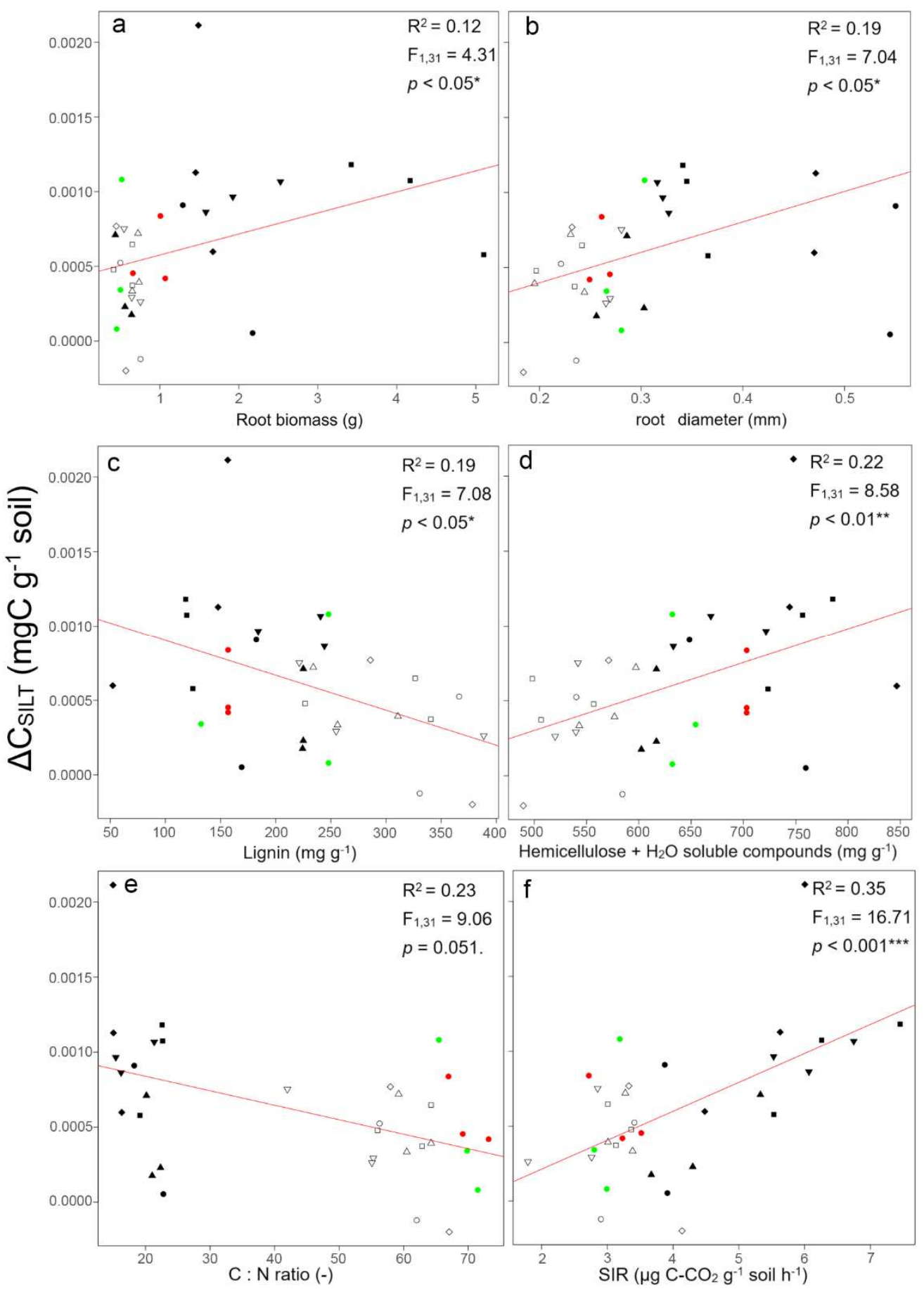
Fig. S11: Linear regression at individual level ( $n=34$ samples) between substrate induced respiration rate

131 (SIR) and a) root biomass, b) lignin content, c) hemicelluloses + water soluble compounds, d) C:N ratio.

132 The black symbols are the $\mathrm{N}_{2}$-fixing Fabaceae species, the white symbols the non $\mathrm{N}_{2}$-fixing Poaceae 133 species, the red dots S. minor and the green dots $P$. lanceolata. The red line is the linear model function 134 of the variables and $R^{2}, F$ and $p$ of the linear model are shown. For the legend refer to figure S9.

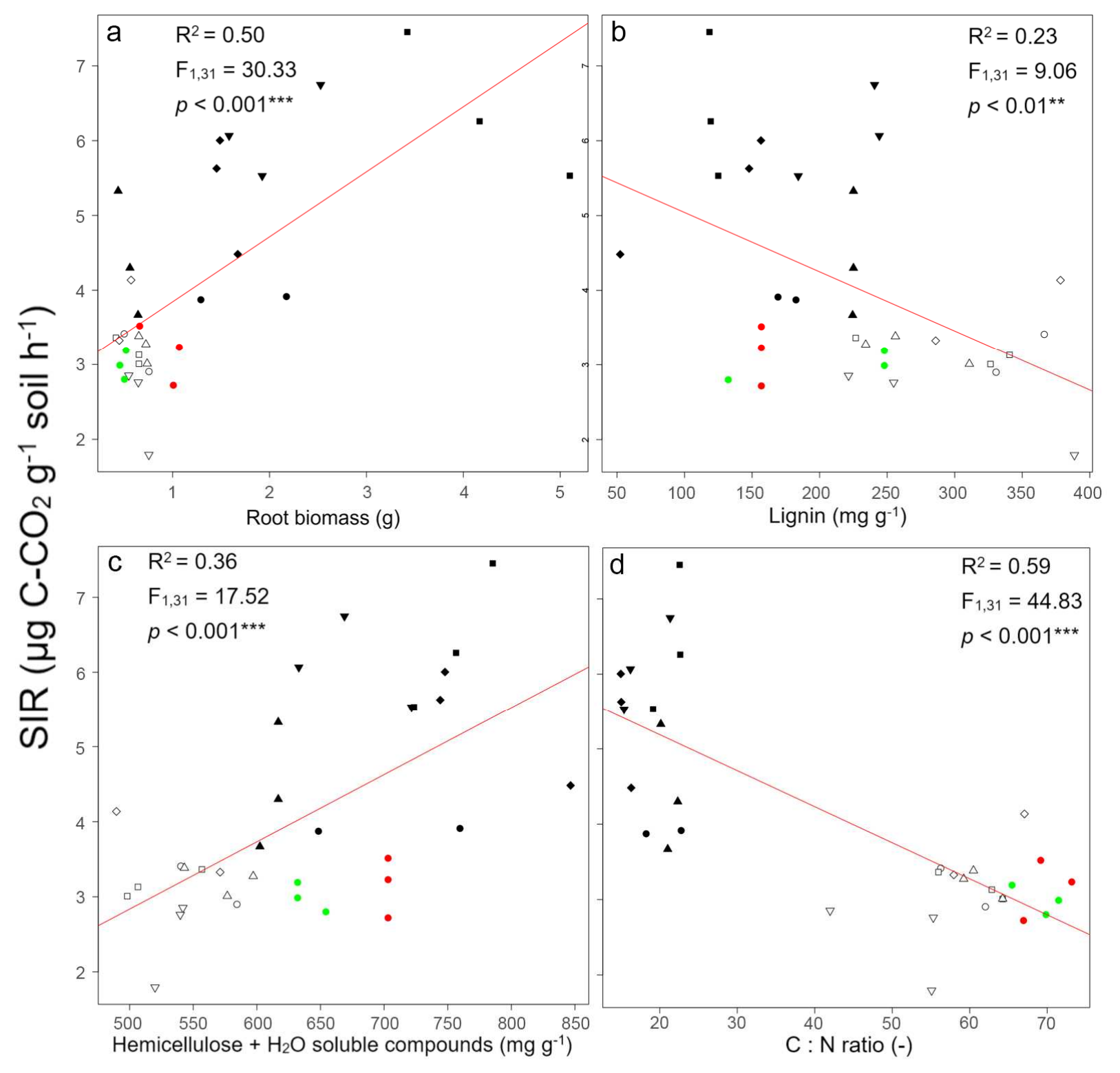

